\title{
Einladung zum 4. Greifswalder Ryck-Symposium
}

Auch in diesem Jahr wird es wieder das „Greifswalder Ryck-Symposium“, die beliebte MTRA-Fortbildungsveranstaltung an der Küste, geben.

Entsprechend unserem bewährten Konzept können sich alle Interessierten am 8. und 9. September auf ein vielfältiges und abwechslungsreiches Programm mit spannenden, lehrreichen Vorträgen von erfahrenen und kompetenten Referenten freuen. In den Pausen werden wieder zahlreiche Firmen für Sie eine Industrieausstellung gestalten.

Und natürlich gehört schon traditionell zum Greifswalder Ryck-Symposium auch das Rahmenprogramm am Freitag. Dieses Mal startet das Segelschulschiff "Greif“ mit den Teilnehmern zu einem Segeltörn auf den Boddengewässern.

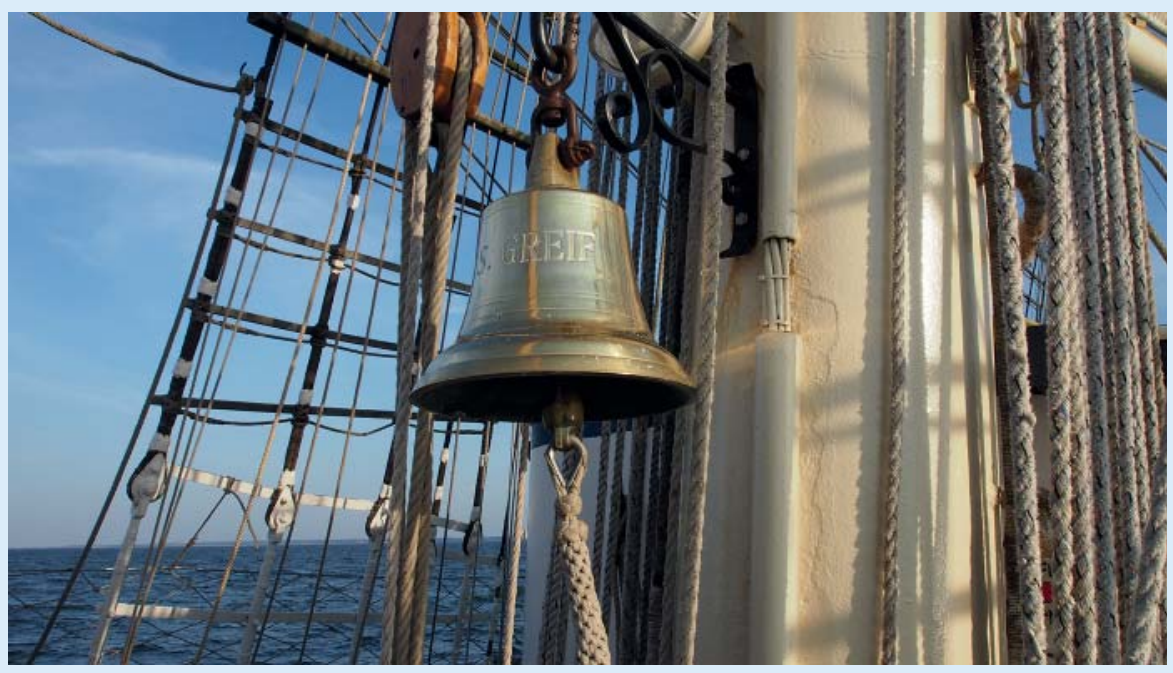

Auf www.vmtb.de finden Sie den Ankündigungsflyer sowie die Möglichkeit zur Anmeldung.

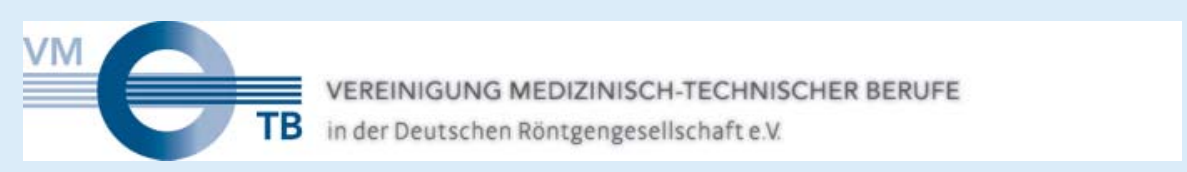

